\title{
EPIDEMIOLOGY OF HUMAN BRUCELLOSIS IN THE UNITED KINGDOM
}

BY

\author{
P. W. BOTHWELL
}

\author{
Department of Public Health, Bristol
}

With the virtual elimination of milk-borne tuberculosis, brucellosis is now the most important milk-borne disease in the United Kingdom. Data relating to the mortality and incidence of brucellosis in the British Isles in recent years have previously been published in connexion with accounts of a survey in the Oxford region (Bothwell, 1960a, b, c, d, 1962). Since the disease may soon be the subject of an eradication scheme for cattle brucellosis, a comparison of the epidemiological factors in six series of cases occurring in the United Kingdom is topical. This comparison is based on data from published work on series of human brucellosis cases reported by Smith (1951), Dalrymple-Champneys (1960), and Bothwell $(1960 \mathrm{a}, \mathrm{b})$; and from unpublished data relating to cases and type of infective organism made available by the courtesy of the Public Health Laboratory Service (two series) and the Health Department of Northern Ireland. The general situation in regard to infection of milking herds is also given.

\section{Age ANd SeX}

The percentage distribution by age and sex in the six series of human cases is shown in Table I. In all six series there is an excess of males in almost all age groups, the exceptions being Champneys's cases (A) aged 60 and over, and the Oxford cases (E) aged 50 and over; also the Oxford series is the only one with an equal proportion of males and females in the 20 to 29 year age group. In five series (A, B, C, D, F) the proportion of children under 10 years ranged from 2.6 to 8.3 per cent., but in the Oxford series it was 19.6 per cent.; the numbers in the Oxford series were small and also there was more than usual paediatric interest in the disease in that area, most of the childhood cases being diagnosed in the latter part of the period surveyed. The small percentages of children aged 0-10 years in the other series are comparable with small percentages found in American series: 3 per cent. under 10 (Magoffin, Kabler, Spink, and Fleming, 1949); $8 \cdot 8$ per cent. under 14 in non-contact cases and $4 \cdot 3$ per cent. in contact cases (Jordan, 1950). Wallis (1959) estimated the incidence of childhood brucellosis to be 1 per cent. of hospital patients, based on observation of 3,000 paediatric cases seen over 5 years; his monograph describes in detail the clinical and epidemiological factors in 35 patients considered to have brucellosis and his are the only recent papers on childhood brucellosis in Great Britain.

Males between the ages of 20 and 40 years make up the majority of cases in all six series. In the more recent Public Health Laboratory Service series (1960-61), the figures kindly supplied by Sir Graham Wilson show that the male : female ratio was $2: 1$ in 1960 but fell to $1 \cdot 6: 1$ in 1961 , the female in-

DISTRIBUTION, BY AGE AND SEX, IN SIX SERIES IN THE BRITISH ISLES

\begin{tabular}{|c|c|c|c|c|c|c|c|c|c|}
\hline \multirow{2}{*}{ Series } & \multirow{2}{*}{ Author } & \multirow{2}{*}{$\begin{array}{c}\text { Date of } \\
\text { Publication }\end{array}$} & \multirow{2}{*}{ Area Covered } & \multirow{2}{*}{$\begin{array}{l}\text { Years } \\
\text { Covered }\end{array}$} & \multirow{2}{*}{$\begin{array}{l}\text { No. of } \\
\text { Cases }\end{array}$} & \multicolumn{2}{|c|}{$0-4$} & \multicolumn{2}{|c|}{$5-9$} \\
\hline & & & & & & M. & F. & M. & $F$ ? \\
\hline A & Dalrymple-Champneys & 1960 & England and Wales .. & $1927-53$ & 1,459 & 0.5 & $0 \cdot 3$ & 3.5 & $1 \cdot N$ \\
\hline B & Wilson & - & $\begin{array}{c}\text { England and Wales Public Health } \\
\text { Laboratory Service }\end{array}$ & 1956-59 & 325 & - & - & $3 \cdot 7$ & $2 \cdot$ \\
\hline C & Smith & 1951 & N.E. Scotland & 1929-50 & 285 & $0 \cdot 4$ & - & $1 \cdot 1$ & $1 \cdot \omega^{2}$ \\
\hline D & - & - & N. Ireland Department of Health .. & 1949-59 & 63 & - & - & $4 \cdot 8$ & 1.8 \\
\hline E & Bothwell & $1960 a, b$ & $\begin{array}{lll}\text { Oxford Area .. } & . . & . . \\
\end{array}$ & 1939-58 & 61 & $\mathbf{8 \cdot 2}$ & $1 \cdot 6$ & 4.9 & $4 . \stackrel{2}{2}$ \\
\hline $\mathbf{F}$ & Wilson & - & $\begin{array}{l}\text { England and Wales Public Health } \\
\text { Laboratory Service }\end{array}$ & $1960-61$ & $169 *$ & $1 \cdot 2$ & - & $5 \cdot 9$ & $1 \cdot \frac{3}{3}$ \\
\hline
\end{tabular}


crease being in adults. This might suggest either that there is a relative increase in the number of women infected by milk or, as Robertson (1962) suggests, that raw meat may be a source of infection for housewives who handle it in preparation for human consumption. A relative increase in milk-borne infection, with a decrease in abortion and handler's risk, seems the most likely of these explanations.

\section{MODES OF INFECTION}

Occupation and Residence.-The occupational percentages (Table II) are useful as a guide to the expected proportion of probable contact infections. Many presumed "occupational contacts" also drink raw milk from infected animals and the exact role played by ingestion and contact is impossible to determine. The percentage of persons in the category "occupationally at risk" varies from $16 \cdot 3$ per cent. in Dalrymple-Champneys's series (A) to 34 per cent. in the Northern Ireland Series (D). The opportunities for contact with animals for persons not in this category must be relatively very few. Infection by auto-injection (Smith, 1951) or by ingestion (Revich, Walker, and Pivnick, 1961) of S.19 living vaccine occurs, but is not epidemiologically significant. Inhalation of organisms into the lungs might be a means of infection for those domiciled on farms (Harper, 1955; Widdicombe, Hughes, and May, 1959).

Elberg and Henderson (1948) pointed out that guinea-pigs were as susceptible to $B r$. suis and $B r$.

TABLE II

\begin{tabular}{|c|c|c|c|c|c|c|c|c|c|c|}
\hline Series & Author & $\begin{array}{l}\text { Date of } \\
\text { Publi- } \\
\text { cation }\end{array}$ & Area Covered & $\begin{array}{c}\text { Years } \\
\text { Covered }\end{array}$ & $\begin{array}{c}\text { No. } \\
\text { of } \\
\text { Cases }\end{array}$ & $\begin{array}{c}\text { Fatality } \\
\text { Rate } \\
\text { (per cent.) }\end{array}$ & $\begin{array}{l}\text { Rural: } \\
\text { Urban } \\
\text { Ratio }\end{array}$ & $\begin{array}{l}\text { Farming } \\
\text { and } \\
\text { Dairying } \\
\text { Occupa- } \\
\text { tions } \\
\text { (per cent.) }\end{array}$ & $\begin{array}{c}\text { Blood } \\
\text { Culture } \\
\text { Positivity } \\
\text { Rate } \\
\text { (per cent.) }\end{array}$ & $\begin{array}{c}\text { Cases } \\
\text { under } 10 \\
\text { years of } \\
\text { age } \\
\text { (per cent.) }\end{array}$ \\
\hline A & $\begin{array}{l}\text { Dalrymple- } \\
\text { Champneys }\end{array}$ & 1960 & England and Wales & $1927-53$ & 1,459 & $1 \cdot 6$ & $\begin{array}{c}\text { Not } \\
\text { known }\end{array}$ & $16 \cdot 3$ & $1 \cdot 2$ & $5 \cdot 6$ \\
\hline B & Wilson & - & $\begin{array}{l}\text { England and Wales Public } \\
\text { Health Laboratory Service }\end{array}$ & $1956-59$ & 325 & $1 \cdot 5 \ddagger$ & $2 \cdot 7: 1$ & $\begin{array}{l}22 \cdot 2 \\
\text { (1957 } \\
\text { only) }\end{array}$ & $2 \cdot 0$ & $6 \cdot 4$ \\
\hline $\mathrm{C}$ & Smith & 1951 & N.E. Scotland & 1929-50 & 285 & $1 \cdot 7$ & $1 \cdot 9: 1$ & $18 \cdot 5$ & $\begin{array}{c}\text { Not } \\
\text { stated* }\end{array}$ & $2 \cdot 45$ \\
\hline $\mathbf{D}$ & - & - & \begin{tabular}{cccc} 
N. Ireland & \multicolumn{2}{c}{ Department of } \\
Health & $\ldots$ & $\ldots$ & $\ldots$
\end{tabular} & $1949-59$ & 63 & 0.0 & $2 \cdot 3: 1$ & $34 \cdot 0$ & $\begin{array}{c}\text { Not } \\
\text { known }\end{array}$ & $6 \cdot 3$ \\
\hline E & Bothwell & $1960 \mathrm{a}, \mathrm{b}$ & $\begin{array}{lll}\text { Oxford Area } & \ldots & \ldots\end{array}$ & 1939-58 & 61 & $1 \cdot 6$ & $3 \cdot 5: 1$ & $22 \cdot 9$ & $3 \cdot 3$ & $19 \cdot 6$ \\
\hline $\mathbf{F}$ & Wilson & - & $\begin{array}{l}\text { England and Wales Public } \\
\text { Health Laboratory Service }\end{array}$ & $1960-61$ & 169 & - & - & $\begin{array}{l}\text { Not } \\
>25\end{array}$ & - & - \\
\hline
\end{tabular}

* In an earlier Scottish series (Beattie, Smith, and Tullock, 1935), the blood culture positivity rate was $23 \cdot 5$ per cent., i.e. twelve of 51 cultures tried.

t Not specifically ascertained in Dalrymple-Champneys's series.

‡ Public Health Laboratory Service (1956-1959) - No. of Deaths recorded by Registrar General

No. of Cases recorded by Public Health Laboraiory Service $=325$ Fatality Rate (per cent.)

LE I

LOSIS

EXPRESSED AS PERCENTAGES OF THE TOTAL NUMBER OF CASES IN EACH SERIES

\begin{tabular}{|c|c|c|c|c|c|c|c|c|c|c|c|c|c|c|c|c|}
\hline \multicolumn{16}{|c|}{ Percentage Age Group (yrs) } & \multirow{3}{*}{$\begin{array}{c}\text { Male : Female } \\
\text { Ratio }\end{array}$} \\
\hline \multicolumn{2}{|c|}{$10-19$} & \multicolumn{2}{|c|}{$20-29$} & \multicolumn{2}{|c|}{$30-39$} & \multicolumn{2}{|c|}{$40-49$} & \multicolumn{2}{|c|}{$50-59$} & \multicolumn{2}{|c|}{69 and Over } & \multicolumn{2}{|c|}{ Not Stated } & \multicolumn{2}{|c|}{ Total All Ages } & \\
\hline M. & F. & M. & F. & M. & F. & M. & F. & M. & F. & M. & F. & M. & F. & M. & F. & \\
\hline $7 \cdot 0$ & $3 \cdot 8$ & $10 \cdot 8$ & $4 \cdot 6$ & $14 \cdot 9$ & $7 \cdot 1$ & $13 \cdot 6$ & $6 \cdot 7$ & $9 \cdot 9$ & $5 \cdot 1$ & $4 \cdot 7$ & $6 \cdot 2$ & - & - & $65 \cdot 0$ & $35 \cdot 0$ & $1 \cdot 9: 1$ \\
\hline $10 \cdot 5$ & $4 \cdot 0$ & $12 \cdot 9$ & $4 \cdot 0$ & $14 \cdot 2$ & $5 \cdot 8$ & $14 \cdot 5$ & $4 \cdot 0$ & $7 \cdot 4$ & $2 \cdot 8$ & $5 \cdot 8$ & $4 \cdot 3$ & $2 \cdot 8$ & 0.6 & $71 \cdot 7$ & $28 \cdot 3$ & $2 \cdot 5: 1$ \\
\hline $5 \cdot 6$ & $2 \cdot 1$ & $12 \cdot 3$ & $9 \cdot 1$ & $19 \cdot 6$ & $8 \cdot 8$ & $13 \cdot 3$ & $5 \cdot 3$ & $6 \cdot 3$ & $5 \cdot 3$ & $5 \cdot 3$ & $4 \cdot 6$ & - & - & $63 \cdot 9$ & $36 \cdot 1$ & $1 \cdot 8: 1$ \\
\hline $3 \cdot 2$ & $3 \cdot 2$ & $9 \cdot 5$ & $3 \cdot 2$ & $15 \cdot 9$ & $3 \cdot 2$ & $15 \cdot 9$ & $7 \cdot 9$ & $9 \cdot 5$ & $4 \cdot 8$ & $7 \cdot 9$ & $1 \cdot 6$ & $4 \cdot 8$ & $3 \cdot 2$ & $71 \cdot 4$ & $28 \cdot 6$ & $2 \cdot 5: 1$ \\
\hline $9 \cdot 8$ & 1.6 & $14 \cdot 8$ & $14 \cdot 8$ & $16 \cdot 4$ & $3 \cdot 3$ & $8 \cdot 2$ & $3 \cdot 3$ & 1.6 & $4 \cdot 9$ & - & 1.6 & - & - & $63 \cdot 9$ & $36 \cdot 1$ & $1 \cdot 8: 1$ \\
\hline $7 \cdot 1$ & $5 \cdot 3$ & $11 \cdot 8$ & $5 \cdot 9$ & $16 \cdot 0$ & $9 \cdot 5$ & $12 \cdot 4$ & $4 \cdot 1$ & 5.9 & $5 \cdot 9$ & 0.6 & 3.6 & 3.0 & 0.6 & $63 \cdot 9$ & $36 \cdot 1$ & $1 \cdot 8: 1$ \\
\hline
\end{tabular}

* There were 185 cases in Series F, but age and sex were unknown in sixteen. 
melitensis by inhalation as by subcutaneous infection. Rapid dissemination via the respiratory tract, and fairly constant cervical and bronchial gland hyperplasia, congestion, and abscess formation, suggested that the lungs and throat were probably important as routes of infection and particularly so in occupationally-exposed groups such as meathandlers.

Harris, Hendrick, Gorman, and Held (1962) reported that 128 persons were affected, over a period of about 9 months, in a swine-slaughtering plant in Iowa. Epidemiological evidence suggested that air-borne transmission from hog to man may have been a prominent factor in this epidemic. 300 swab samples taken from surfaces and a total of 480 cubic feet of air were sampled by three sampling devices. Brucellae were recovered in 10 cubic feet of air from a slit sampler and another organism was isolated from a settling plate, both specimens of virulent Br. suis.

Barrett and Rickards (1953), in a small series of 25 cases in a mainly agricultural area, found that 56 per cent. of the patients were in farming occupations. Similarly, in the Oxford series, taking cases occurring in groups in rural areas only, the proportion occupationally at risk rises to just over 50 per cent. (11 out of 21). McWhinney and Prior (1961) found a latent infection rate (titre 1/40) of 70 per cent. in twenty farmers. The rural : urban ratio is high in the Northern Ireland series (D), where also there is the highest occupational group (34 per cent.), and in the Public Health Laboratory Service serieswhere the occupational group is 22 per cent.

Role of Milk.-Dalrymple-Champneys considered that 82 per cent. of his cases were due to the ingestion of infected milk. Wilson (1961) considers that in the P.H.L.S. data there is evidence that most of the town cases are due to T.T. milk infected with brucellae. In the Oxford series 80 per cent. of the patients appeared to have derived their infection from milk, often tuberculin-tested. In Scotland, Beattie, Smith, and Tulloch (1935) commented on the heavy milkdrinking of some of their patients; Smith (1951), who reported on and extended Beattie's series, referred to multiple cases in one family which were attributable to a common infected milk supply. There is no evidence about the role of milk in the Northern Ireland series, as this information is not included in the case histories reported to the Health Department there.

Role of Insect Vectors.-Though not certain, this does not appear to be of significance in the United Kingdom (McDiarmid, 1961).

\section{TYPE OF ORganisM}

Blood cultures were positive in $1 \cdot 2,2 \cdot 0$ and $3 \cdot 3$ per cent. respectively of the cases in Series A, B, and E (Table II); data were not available on this point for Series $C, D$, and $F$.

Br. abortus has always been the predominant organism in the United Kingdom in cases of human infection in which the organism has been typed, and in reports of infected milk and animal products of conception. However both groups in recent years have shown an increase in the proportion of $B r$. melitensis and its variant organisms. Brinley-Morgan (1960) and Stableforth (1960) reported a continuing rise in the percentage of Br. melitensis and melitensislike organisms in aborted material and in milk submitted for examination, from a total of 38 herds infected in 1940-50 to a total of 112 herds infected in 1951-56. Strains of brucella from milk and genital sources isolated in Britain in 1958-59 (415 strains) showed 8.7 per cent. Br. melitensis in milk and 11.4 per cent. in genital material.

An analysis of Brucella strains typed between October, 1956, and December, 1960 at the Brucella Reference Laboratory (Payne, 1961) is shown in Table III (opposite); the figures in brackets are taken from the analysis made by Cruickshank (1954) of Brucella strains typed when he was operating the Brucella Reference Laboratory.

There has been a considerable rise in the number of isolations of the so-called Br. melitensis and a reduction of the dye-sensitive strains by about half; in this period of $4 \frac{1}{2}$ years, only eight strains of brucella from human subjects were typed. In the same period the number of brucellosis cases reported to the Public Health Laboratory Service would, on an average of ninety per annum, total nearly 400 . It seems therefore that the organism is available for typing in only about 2 per cent. of these human infections. This probably represents rather less than the blood culture positives actually found, which must be nearer 4 per cent. of human cases. Since the organism is typed in so few human cases and $\mathrm{Br}$. melitensis was isolated in cows 81 times, it is possible that, if all the cases in the human series had been cultured and typed, a certain number might have been shown to be due to Br. melitensis. In recent weeks such a case has in fact occurred, Payne (1962) recovered Br. melitensis (British variety) by culture and serum agglutinin absorption techniques from a child in Lincolnshire. However, the view is now widely held that the so-called $B r$. melitensis in Britain is merely a variant of $\mathrm{Br}$. abortus.

$B r$. melitensis and Br. suis have been cultured and diagnosed from agglutinations in human cases in 
TABLE III

BRUCELLA STRAINS TYPED AT THE BRUCELLA REFERENCE LABORATORY (PAYNE, 1961)

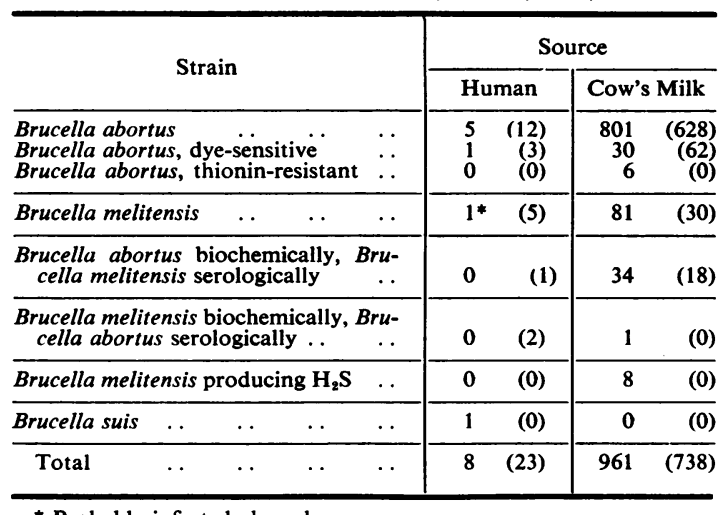

* Probably infected abroad.

Ireland (O’Doherty, 1959; Williams, Entwistle, Masters, and Woods, 1957).

\section{INFECTION IN MILK AND INCIDENCE OF Human BRUCELlosis}

In the recent survey carried out in England and Wales by the Ministry of Agriculture, provisional results appear to indicate that herd infection is about 22 per cent. (varying from 11 to 30 per cent. from region to region), and that overall about 1 per cent. (i.e. about 32,000 cows) are secreting infected milk. The Public Health Laboratory Service (1961) and also the studies made by McDiarmid (1960) in the Oxford area have indicated that 4 to 5 per cent. of churn milk supplies are infected.

Although the percentages of milk pasteurized in Britain are high (England and Wales 94 per cent., Northern Ireland 93 per cent., Scotland 78 per cent.), there is no evidence for a falling-off in the incidence of recognized human cases of brucellosis. The Public Health Laboratory Service figures (Wilson, 1961), which provide the most recent available evidence, show the numbers of cases reported from 1945 to 1961 (Table IV). It cannot be doubted that there were more human cases of brucellosis than were reported to the P.H.L.S. and Table IV clearly cannot represent more than a fraction of the actual

TABLE IV

CASES OF HUMAN BRUCELLOSIS REPORTED TO THE P.H.L.S. YEARLY, 1945-1961

\begin{tabular}{cc|cc|cc}
\hline Year & Cases & Year & Cases & Year & Cases \\
\cline { 1 - 4 } 1945 & 78 & 1951 & 105 & 1957 & 90 \\
1946 & 69 & 1952 & 94 & 1958 & 78 \\
1947 & 56 & 1953 & 133 & 1959 & 87 \\
1948 & 67 & 1954 & 117 & 1960 & 84 \\
1949 & 68 & 1955 & 119 & 1961 & 101 \\
1950 & 100 & 1956 & 92 & & \\
\hline
\end{tabular}

incidence of human brucellosis. The numbers of new cases in recent years must be due in some measure to improved diagnosis, but other factors may play a part.

\section{CRoss-IMmunity IN BRUCELlosis}

A review has been published elsewhere (Bothwell, 1962) of work showing an interesting cross-immunity, dependent on mononuclear cell reaction, between tuberculosis and brucella organisms.

Pullinger (1936) suggested, from observations on guinea-pigs, that the mononuclear cell reaction stimulated by tubercle bacilli destroyed $\mathrm{Br}$. abortus. Observations on the blood picture in brucellosis by Rainsford (1935) and Munger (1940) often showed mononucleosis; increase in these cells, according to Rainsford, indicated a good prognosis. PomalesLebron and Stinebring (1957) showed that, in $B r$. abortus-immune phagocyte systems, multiplication of the organism was significantly restricted. Elberg, Schneider, and Fong (1957) thought this was due to specific cellular activity, and later Elberg and Meyer (1958) confirmed that mononuclears stimulated by tuberculosis are resistant to destruction by tubercle as well as by brucellae. Ralston and Elberg (1960) isolated a lysozyme-like material from rabbit monocytes. Elberg and others (1957) found that BCG protected against brucellosis in rabbits, and Bekierkunst and Sulitzeanu (1958) demonstrated the same thing in mice.

From this it is possible to speculate that the generally falling rate of tuberculin positivity in man, and particularly in children, may be associated with increased susceptibility to brucellosis, so that smaller doses may more easily result in clinical infection. Tuberculin skin positivity and brucellergen skin positivity should perhaps be negatively correlated. Angle, Algie, Baumgartner, and Lunsford (1938) noted the absence of positive correlation between these two tests. Also it might be suspected that tuberculin positivity resulting from infection or from BCG vaccine ought to prevent brucellosis, and that tuberculin positives should be negatively related to brucella agglutinins, both by tube test and by blocking antibody test. A similar epidemiological argument may also apply to animals where tuberculosis has been eradicated, and this may be responsible for the continuing excretion of field strains of $\mathbf{B r}$. abortus by animals.

\section{Outstanding Problems}

At present, important fields for progress in the control and elimination of this disease in the United Kingdom are as follows:

(1) Effective legislation to deal with the disease. 
(2) Standardization of antigens used in agglutination tests in the various laboratories, and of the use of the blocking antibody test and its evaluation.

(3) More concentrated effort to culture the organism, using the latest media, including embryonated egg.

(4) Refinement of brucellin to obtain a strainspecific, non-agglutinogenic test for epidemiological use.

(5) Field studies using this material and correlation with tuberculin tests.

(6) Investigation of the role of Brucella in inducing arthritic sequelae, particularly disk lesions and osteophytic lesions of the vertebral bodies, a subject on which there is an extensive and increasing literature from other countries.

(7) Studies in endemic areas, with $x$ ray and serological tests concentrating on the rural farming populations.

\section{SUMMARY}

Six series of cases of human brucellosis in the United Kingdom are compared. Most of the patients were males aged between 20 and 40, the male : female ratio ranging from $1 \cdot 8: 1$ to $2 \cdot 5: 1$. Children under 10 years of age constituted from 2.6 to $8 \cdot 3$ per cent. of cases in five series, but in one small series of 61 cases (E) the proportion was about 19.6 per cent., this being attributed partly to exceptional paediatric interest in the area and to the fact that the numbers involved were small.

Brucella organisms were cultured in $1 \cdot 2,2$, and $3 \cdot 3$ per cent. of cases in three series (A, B, E). Since so few human blood cultures are positive, it is not possible to say whether the increasing incidence of $\mathrm{Br}$. melitensis-like organisms in cattle is associated with human disease. A recent case due to $B r$. melitensis of a British variety indicates that cases are probably occurring more often than is thought.

The proportion of the patients who were at occupational risk from contact with animals varied from $16 \cdot 3$ to 34 per cent. The rural : urban ratios varied from $1 \cdot 9: 1$ to $3 \cdot 5: 1$.

Milk was cited as the predominant infective agency in four of these series where the point was studied. Though pasteurization of milk is at a high level, the remaining 4 to 5 per cent. of raw milk apparently provides a continuing source of infection for the human subject, from the 1 per cent. of cows which are excretors in the 11 to 30 per cent. of infected herds. Diminished cross-immunity to brucellosis, associated with falling tuberculin positivity, may have some bearing on this situation, and similar epidemiological factors may apply to the animals themselves.
Outstanding problems in the study and control of brucellosis are enumerated.

\section{REFERENCES}

Angle, F. E., Algie, W. H., Baumgartner, L., and Lunsford, W. F. (1938). Ann. intern. Med., 12, 495.

Barrett, G. M., and Rickards, A. G. (1953). Quart. J. Med., 22, 23.

Beattie, C. P., Smith, J., and Tulloch, W. J. (1935). Lancet, $1,1427$.

Bekierkunst, A., and Sulitzeanu, D. (1958). Nature (Lond.), 182, 883.

Bothwell, P. W. (1960a). Med. Offr., 103, 85.

- (1960b). Vet. Rec., 72, 425.

- (1960c). Ibid., 72, 933.

- (1961). Publ. Hlth (Lond.), 75, 276.

- (1962). Arch. Dis. Child., 37, 628.

Brinley-Morgan, W. J. (1960). Personal communication.

Cruickshank, J. C. (1954). J. Hyg. (Lond.), 52, 105.

Dalrymple-Champneys, W. (1960). "Brucella Infection and Undulant Fever in Man." Oxford University Press, London.

Elberg, S. S., and Henderson, D. W. (1948). J. infect. Dis., 82, 302.

and Meyer, K. F. (1958). Bull Wld Hlth Org., 19, 711.

106, 545 .

Harper, G. J. (1955). Brit. J. exp. Path., 36, 60.

Harris, M. M., Hendricks, S. L., Gorman, G. W., and Held, J. R. (1962). Publ. Hlth Rep. (Wash), 77, 602.

Jordan, C. F. (1950). In "Brucellosis. A Symposium" p. 101. American Association for the Advancement of Science, Washington.

McDiarmid, A. (1961a) Publ. Hlth (Lond.), 75, 268. (1961b). Personal communication.

McWhinney, I., and Prior, A. P. (1961). Brit. med. J., 2, 80.

Magoffin, R. L., Kabler, P., Spink, W. W., and Fleming, D. (1949), Publ. Hlth Rep. (Wash.), 64, 1021.

Ministry of Health (1961). Monthly Bull. Minist. Hlth Lab. Serv., 20, 33.

Munger, M. (1940). Tech. Bull. No. 177, Michigan Agric. Exp. Stn., p. 35.

O'Doherty, R. (1959). J. Irish med. Ass., 44, 134.

Payne, D. J. H. (1961). Personal communication, from PHLS Brucella Ref. Lab.

(1962). Ibid.

Pomales-Lebron, A., and Stinebring, W. R. (1957). Proc. Soc. exp. Biol. (N.Y.), 94, 78.

Pullinger, E. J. (1936), J. Hyg. (Lond.), 36, 456.

Rainsford, S. G. (1933). J. roy. nav. med. Serv., 19, 1.

Ralston, D. J., and Elbert, S. S. (1960). Proc. Soc. exp. Biol. (N.Y.), 104, 464.

Revich, S. J., Walker, A. W., and Pivnick, H. (1961). Canad. J. publ. Hlth, 52, 295.

Robertson, J. S. (1962). Personal communication.

Smith, J. (1951). Hlth Bull. (Edinb.), 9, 57.

Stableforth, A. W. (1960). Personal communication.

Wallis, H. R. E. (1959). "Brucellosis in England". O'Connor, London.

Widdicombe, J. G., Hughes, R., and May, A. J. (1959). Brit. J. exp. Path., 40, 125.

Williams, T. P., Entwistle, D. M., Masters, P. L., and Woods, A. C. (1957). Lancet., 2, 1203.

Wilson, G. S. (1961). Personal communication. (1962). Ibid. 